\title{
Detection of multiple respiratory pathogens during primary respiratory infection: nasal swab versus nasopharyngeal aspirate using real-time polymerase chain reaction
}

\author{
T. J. Meerhoff • M. L. Houben • F. E. J. Coenjaerts • \\ J. L. L. Kimpen • R. W. Hofland • F. Schellevis • \\ L. J. Bont
}

Received: 27 October 2009 / Accepted: 21 December 2009 /Published online: 29 January 2010

(C) The Author(s) 2010. This article is published with open access at Springerlink.com

\begin{abstract}
In this study, we present the multiple detection of respiratory viruses in infants during primary respiratory illness, investigate the sensitivity of nasal swabs and nasopharyngeal aspirates, and assess whether patient characteristics and viral load played a role in the sensitivity. Healthy infants were included at signs of first respiratory tract infection. Paired nasopharyngeal aspirates and nasal swabs were collected. Real-time polymerase chain reaction (PCR) was carried out for 11 respiratory pathogens. Paired nasopharyngeal aspirates and nasal swabs were collected in 98 infants. Rhinovirus $(n=67)$ and respiratory syncytial virus $(n=39)$ were the most frequently detected. Co-infection occurred in $48 \%(n=45)$ of the infants. The sensitivity of the nasal swab was lower than the nasopharyngeal aspirate, in particular, for respiratory syncytial virus (51\% vs. $100 \%)$ and rhinovirus (75\% vs. $97 \%)$. The sensitivity of the nasal swab was strongly determined by the cycle threshold (CT)
\end{abstract}

T. J. Meerhoff $\cdot$ F. Schellevis

NIVEL: Netherlands Institute for Health Services Research,

Utrecht, The Netherlands

T. J. Meerhoff

e-mail: t.meerhoff@nivel.nl

M. L. Houben · J. L. L. Kimpen · R. W. Hofland • L. J. Bont ( $\square)$ Department of Paediatrics, University Medical Centre Utrecht, Utrecht, The Netherlands

e-mail: 1.bont@umcutrecht.nl

F. E. J. Coenjaerts

Department of Virology, University Medical Centre Utrecht, Utrecht, The Netherlands

F. Schellevis

Department of General Practice/EMGO Institute,

VU University Medical Centre Amsterdam,

Amsterdam, The Netherlands value $(p<0.001)$. The sensitivity of the swab for respiratory syncytial virus, but not rhinovirus, was $100 \%$ in children with severe symptoms (score $\geq 11$ ). It is concluded that, for community-based studies and surveillance purposes, the nasal swab can be used, though the sensitivity is lower than the aspirate, in particular, for the detection of mild cases of respiratory syncytial virus (RSV) infection.
Abbreviations
NS Nasal swab
NPA Nasopharyngeal aspirate
PCR Polymerase chain reaction
hMPV Human metapneumovirus
RSV Respiratory syncytial virus

\section{Background}

Respiratory viruses are a common cause of illness in children, in particular during their first years of life, and may lead to more severe morbidity and hospitalisation [1-4]. Different types of specimen are available for viral diagnosis. The nasopharyngeal aspirate (NPA) has been considered to be the best sampling technique, but is more invasive and results in significantly more distress of the infant than a nasal swab (NS) [5]. A number of studies have compared the sensitivity of the NPA with nasopharyngeal swabs [6], nose-throat swabs [7] and NS [5, 8-10]. Generally, conventional techniques such as viral culture and antigen detection methods were used. The use of realtime polymerase chain reaction (PCR) may overcome differences in sensitivity for respiratory viruses as a result of specimen type [7].

Limited data are available on the comparison of these sampling methods combined with real-time PCR. It was 
observed that nose-throat swabs are a less invasive diagnostic technique, with adequate sensitivity for use in outpatient and large community-based settings in children [7]. However, no tests were performed for rhinovirus, even though this virus commonly infects infants [11]. The aim of this study was to present the detection of common respiratory pathogens in infants during primary respiratory illness, to investigate the sensitivity of the NS and NPA, and assess the role of patient characteristics and viral load in the sensitivity of either sampling method.

\section{Study design}

\section{Study cohort}

The study is part of the Netherlands Amnion Fluid Study of the Utrecht University Medical Centre (UUMC), the Netherlands [12]. Healthy infants were included at birth and were at risk for primary respiratory infection until the age of one year. The data collection and episode sampling stopped one year after birth. From April 2006 to April 2008, including two winter seasons, paired NPA and NS specimens were obtained from 98 infants. Parents were instructed to notify the clinical staff within $24 \mathrm{~h}$ after the onset of symptoms. Clinical staff visited the child within $36 \mathrm{~h}$ and the history of illness was taken by a standardised questionnaire. Symptoms were scored, according to Gern et al. [13], with points presented in parentheses: fever $\left(>38^{\circ} \mathrm{C}\right)$ (1); cough, mild (1), moderate (2), severe (3); rhinorrhoea, mild (1), moderate to severe (2); hoarseness (1); duration of illness $>4$ days (1); apnoea (3); wheezing (5); retractions (5); tachypnoea (5); cyanosis (5). Mild, moderate and severe infection were defined as sum scores $0-4,5-10$ and 11 and higher, respectively. Specially trained clinical staff obtained paired NS and NPA.

\section{Collection of specimens}

The NPA was obtained by the use of an infant mucus extractor (Vygon). Both nostrils were suctioned. In addition, an NS was collected; samples were collected from one nostril and one from the hard palate using separate cottontipped swabs (Infant Mucus Extractor, Vygon Pharmaceutiques, Ecouen, France). The two swabs were then inserted into one vial containing $2 \mathrm{ml}$ of virus transport medium (Gly medium).

\section{Real-time PCR}

Semi-quantitative real-time PCR was conducted on both the NS and NPA for respiratory syncytial virus (RSV), rhinovirus, human metapneumovirus, adenovirus, corona- virus, influenza, parainfluenza virus (type 1, 3), parainfluenza (type 2,4), bocavirus, Mycoplasma pneumoniae and Chlamydia pneumoniae. Nucleic acids were extracted using the QIAamp DSP virus kit (QIAGEN, Valencia, CA, USA). Each sample was eluted in $200 \mu \mathrm{l}$ buffer. cDNA was synthesised by using MultiScribe reverse transcriptase (RT) and random hexamers (both from Applied Biosystems, Foster City, CA, USA) [14]. Each 100- $\mu$ l reaction mixture contained $60 \mu \mathrm{l}$ cDNA mix and $40 \mu \mathrm{l}$ of eluted RNA. After incubation for $10 \mathrm{~min}$ at $25^{\circ} \mathrm{C}$, RT was carried out for $30 \mathrm{~min}$ at $48^{\circ} \mathrm{C}$, followed by RT inactivation for $5 \mathrm{~min}$ at $95^{\circ} \mathrm{C}$ [14]. Samples were assayed in a $50-\mu l$ reaction mixture containing $20 \mu \mathrm{l}$ (c)DNA and a $30-\mu \mathrm{l}$ mix of the forward and reverse primers and probes. All samples had been spiked before extraction with an internal control virus (murine encephalomyocarditis virus [RNA] and phocine herpes virus [DNA]). The amplification and detection were performed by the use of an ABI Prism 7700 sequencedetection system; $2 \mathrm{~min}$ at $50^{\circ} \mathrm{C}$ to acquire optimal AmpErase UNG activity and $10 \mathrm{~min}$ at $95^{\circ} \mathrm{C}$ to activate AmpliTaq Gold DNA polymerase, followed by 45 cycles of $15 \mathrm{~s}$ at $95^{\circ} \mathrm{C}$ and $1 \mathrm{~min}$ at $60^{\circ} \mathrm{C}$ [15]. Primers and probes for the real-time PCR detection of RSV, influenza virus, parainfluenza virus and adenovirus are available from van de Pol et al. [16] and real-time PCR assays were performed as described previously [17-19].

\section{Statistical analysis}

Similar to previous studies, a consensus standard was used to assess the sensitivity of each testing method: a positive result in either the NPA or NS was considered as the gold standard for the presence of a pathogen and was used to calculate the sensitivity of the NPA and NS for the detection of the respiratory pathogens. The Chi-square test was used and a logistic regression analysis was performed. The outcome variable was defined as the sample being positive. Variables used in the model were age, gender, symptom score and multiple virus detection. Statistical significance was concluded if the $p$-value was $<0.05$. The statistical analyses were performed in STATA 10.0 (StataCorp LP, College Station, TX, USA).

\section{Results}

A total of 163 respiratory pathogens were identified in 94 children. The majority of children $(73.5 \%)$ were ill for less than 4 days at the time of sampling. The median age at primary infection was 104 days (range 33-269) and the median score of symptoms was 3 , indicating a mild illness (Table 1). In all children with an illness of 5 days or longer, one or more pathogens were detected. 
Table 1 Characteristics of infants during the first airway infection

\begin{tabular}{|c|c|c|c|}
\hline Characteristics & All infants $(N=98)$ & Rhinovirus detected $(n=67)$ & RSV detected $(n=39)$ \\
\hline Median age in days (range) & $104(33-269)$ & $99(33-269)$ & $115(51-269)$ \\
\hline Median days of illness at time sampling (range) & $3.5(2-31)^{\mathrm{c}}$ & $4(2-16)$ & $4(2-12)$ \\
\hline$\%$ male & $58 \%$ & $60 \%$ & $62 \%$ \\
\hline \multicolumn{4}{|l|}{ Symptoms } \\
\hline \multicolumn{4}{|l|}{ Rhinorrhoea } \\
\hline None & $15 \%$ & $15 \%$ & $18 \%$ \\
\hline Mild & $55 \%$ & $58 \%$ & $46 \%$ \\
\hline Moderate-severe & $30 \%$ & $27 \%$ & $36 \%$ \\
\hline \multicolumn{4}{|l|}{ Cough } \\
\hline None & $17 \%$ & $18 \%$ & $5 \%$ \\
\hline Mild & $36 \%$ & $46 \%$ & $28 \%$ \\
\hline Moderate & $37 \%$ & $30 \%$ & $46 \%$ \\
\hline Severe & $10 \%$ & $6 \%$ & $21 \%$ \\
\hline Wheezing $^{\mathrm{a}}$ & $8 \%$ & $6 \%$ & $10 \%$ \\
\hline Fever $>38^{\circ} \mathrm{C}$ & $17 \%$ & $12 \%$ & $23 \%$ \\
\hline Hoarseness & $28 \%$ & $22 \%$ & $31 \%$ \\
\hline Apnoea $^{\mathrm{b}}$ & $3 \%$ & $2 \%$ & $5 \%$ \\
\hline Cyanosis & $1 \%$ & $0 \%$ & $3 \%$ \\
\hline Retractions & $6 \%$ & $3 \%$ & $5 \%$ \\
\hline Tachypnoea & $20 \%$ & $16 \%$ & $28 \%$ \\
\hline Median sum score (range) & $3(0-25)$ & $3(0-15)$ & $4(1-25)$ \\
\hline $0-4$ & $64 \%$ & $72 \%$ & $56 \%$ \\
\hline $5-10$ & $25 \%$ & $22 \%$ & $26 \%$ \\
\hline$>10$ & $11 \%$ & $6 \%$ & $18 \%$ \\
\hline
\end{tabular}

The values represent percentages, unless indicated otherwise

${ }^{\text {a }}$ Reported by parents

${ }^{\mathrm{b}} N=97$

${ }^{\mathrm{c}}$ Duration of illness: IQR $=3-5$

Multiple pathogens in half of the children

In 49 children (50\%), one pathogen was detected: 29 rhinovirus, $11 \mathrm{RSV}$, four coronavirus, two hMPV, two parainfluenza virus type 2 and 4 , and one bocavirus. In 25 children, two pathogens were detected, of which 24 (96\%) were rhinovirus with RSV. In 20 children, more than two pathogens were detected during the first episode of respiratory symptoms (three pathogens: $n=$ 17; four pathogens: $n=2$; five pathogens: $n=1$ ). Coinfection rates by pathogen were: rhinovirus $(57 \%)$, hMPV $(60 \%)$, RSV (72\%), coronavirus $(71 \%)$ and bocavirus $(91 \%)$.

Sensitivity of nasal swab is lower than the aspirate for RSV and rhinovirus

Rhinovirus was found the most frequently $(n=67)$, followed by RSV $(n=39)$ and coronavirus $(n=14)$ (Table 2).
No influenza viruses or parainfluenza type 1 and 3 viruses were detected. The sensitivity for detecting any pathogen of the NPA was $92 \%\left(\mathrm{CI}_{95 \%}\right.$ 86.7-95.7), whereas the sensitivity of the NS was lower at $67 \%\left(\mathrm{CI}_{95 \%} 59.1-\right.$ 74.0). For the detection of RSV and rhinovirus, the sensitivity of the NS was lower than the NPA (Table 2).

Sensitivity of nasal swab depends on viral load

The sensitivity values of the NPA and NS were investigated in more detail for rhinovirus and RSV (Table 3). For children with a low symptom score, the sensitivity of the NS was lower than the NPA. The NS had a lower sensitivity than the NPA for the 30-40 cycle threshold (CT) values. To assess whether the sensitivity of the NS differed by age group, gender, multiple pathogens, symptom score and CT value, Chi-squared tests were performed. The sensitivity of the NS for the detection of RSV was related to the symptom score $(p=0.001)$ and the sensitivity 
Table 2 Detection of respiratory pathogens and the sensitivity by sampling method

\begin{tabular}{|c|c|c|c|c|c|c|c|}
\hline \multirow[t]{2}{*}{ Respiratory pathogen } & \multirow[t]{2}{*}{ NPA $(n)$} & \multirow[t]{2}{*}{$\mathrm{NS}(n)$} & \multirow[t]{2}{*}{ Total } & \multicolumn{2}{|l|}{ NPA } & \multicolumn{2}{|l|}{ NS } \\
\hline & & & & Sensitivity & $95 \% \mathrm{CI}^{*}$ & Sensitivity & $95 \% \mathrm{CI}^{*}$ \\
\hline Rhinovirus & 65 & 50 & 67 & $97 \%$ & $89.6-99.6$ & $75 \%$ & $62.5-84.4$ \\
\hline RSV & 39 & 20 & 39 & $100 \%$ & $91.0-100$ & $51 \%$ & $34.8-67.6$ \\
\hline Coronavirus & 13 & 10 & 14 & $93 \%$ & $66.1-99.8$ & $71 \%$ & $41.9-91.6$ \\
\hline Bocavirus & 8 & 7 & 11 & $73 \%$ & $39.0-94.0$ & $64 \%$ & $30.8-89.1$ \\
\hline Adenovirus & 9 & 6 & 11 & $82 \%$ & $48.2-97.7$ & $55 \%$ & $23.4-83.3$ \\
\hline Parainfluenza type 2 and 4 & 9 & 9 & 11 & $82 \%$ & $48.2-97.7$ & $82 \%$ & $48.2-97.7$ \\
\hline hMPV & 4 & 3 & 5 & $80 \%$ & $28.4-99.5$ & $60 \%$ & $14.7-94.7$ \\
\hline Mycoplasma pneumoniae & 2 & 2 & 3 & $67 \%$ & $9.4-99.2$ & $67 \%$ & $9.4-99.2$ \\
\hline Chlamydia pneumoniae & 1 & 2 & 2 & $50 \%$ & $1.2-98.7$ & $100 \%$ & $15.8-100$ \\
\hline Total & 150 & 109 & 163 & $92 \%$ & $86.7-95.7$ & $67 \%$ & $59.1-74.0$ \\
\hline
\end{tabular}

NPA: nasopharyngeal aspirate; NS: nasal swab; RSV: respiratory syncytial virus; hMPV: human metapneumovirus; CI: confidence interval

*A one-sided $97.5 \%$ confidence interval was used in case the sensitivity was $100 \%$

of the NS was related to the CT values for both RSV and rhinovirus $(p<0.001)$.

In the logistic regression analysis, age and gender did not significantly predict the detection of RSV or rhinovirus. The symptom score predicted RSV detection in both the NPA (odds ratio [OR]: $1.21 ; \mathrm{CI}_{95 \%} 1.07-1.39$ ) and the NS (OR: 1.28; $\mathrm{CI}_{95 \%}$ 1.12-1.48), while an inverse relationship was observed for symptom score and rhinovirus detection in the two samples (OR: $0.87 ; \mathrm{CI}_{95 \%} 0.78-0.98$ ). The presence of more than one pathogen predicted RSV (OR: 8.98; $\mathrm{CI}_{95 \%}$ 3.03-26.7) or rhinovirus detection (OR: 3.66 $\mathrm{CI}_{95 \%}$ 1.33-10.08) in the NPA. When the same analysis was performed as a backwards regression with $p<0.2$, the results did not change.

\section{Discussion}

This study illustrates that the proportion of infants where a respiratory pathogen is detected was high $(96 \%)$ and coinfections were common. In 20 children, more than two pathogens were detected during the first episode of respiratory symptoms. Co-infections were observed frequently for RSV (72\%), coronavirus (71\%) and bocavirus $(91 \%)$ in particular.

High rates of co-infection in young children have been described recently for childhood pneumonia, in particular, in children aged less than 12 months [20] and in children hospitalised with acute respiratory tract infection [21, 22]. The most frequently detected virus was RSV, followed by human bocavirus and rhinovirus [21, 23]. A common combination has been reported to be RSV and bocavirus [21]. Even though a high occurrence of co-infections has been reported, ranging from $14-16 \%[21,22]$ to $27 \%$ [20], our study presents an even higher rate of co-infection. A possible explanation for this high co-infection rate may be related to the sampling of both nostrils for the NPA. Human bocavirus is a newly identified virus and has been detected in respiratory tract secretions in patients with acute respiratory symptoms in 2 to $19 \%$ of the samples [24]. Co-infection with another virus has been observed in $40 \%$ of bocaviruspositive children [25]. The frequent associations of bocavirus with other respiratory viruses might be explained by the persistence of bocavirus in the respiratory tract [25].

Furthermore, we investigated the sensitivity of the NPA and NS tested by a real-time PCR method. The sensitivity of the NPA was $92 \%$, while for the NS, it was $67 \%$. In particular for the detection of rhinovirus and RSV, the NS had a lower sensitivity ( $75 \%$ and $51 \%$, respectively) compared to the NPA ( $97 \%$ and $100 \%$, respectively). The sensitivity of the NS for RSV was $100 \%$ for children with high symptom scores. For both RSV and rhinovirus, viral load, indicated by the CT value, was the major determinant of the sensitivity of the NS in a dose-dependent fashion. The symptom score predicted RSV detection in both the NPA and the NS, while an inverse relationship was observed for symptom score and rhinovirus detection in the two samples.

The use of a swab has been considered as a suitable replacement in community-based research or epidemiological studies. The major advantage of a swab is that collection is less painful and more convenient than an aspirate, as no additional devices are needed [5]. These factors may outweigh some reduction in sensitivity. The advantage of molecular methods in the detection of respiratory viruses has been reported [26, 27] and Lambert et al. reported that using these methods seemed to overcome the previously observed sensitivity reduction when less invasive specimens were combined with the conventional laboratory methods [7]. With the recently 
Table 3 Sensitivity of the NPA and NS for the detection of rhinovirus and RSV presented by age group, gender, symptom score, presence of multiple pathogens and CT-value of the NPA

\begin{tabular}{|c|c|c|c|c|c|c|c|c|}
\hline \multirow[t]{2}{*}{ Respiratory pathogen } & \multirow[t]{2}{*}{ subgroups } & \multirow{2}{*}{$\begin{array}{l}\text { NPA } \\
\text { (n) }\end{array}$} & \multirow{2}{*}{$\begin{array}{l}\text { NTS } \\
\text { (n) }\end{array}$} & \multirow[t]{2}{*}{ Total } & \multicolumn{2}{|l|}{ NPA } & \multicolumn{2}{|l|}{ NS } \\
\hline & & & & & Sensitivity & $95 \% \mathrm{CI}^{\mathrm{a}}$ & Sensitivity & $95 \% \mathrm{CI}^{\mathrm{a}}$ \\
\hline \multicolumn{9}{|l|}{ Rhinovirus } \\
\hline \multirow[t]{3}{*}{ Age } & $1-3$ months & 28 & 24 & 28 & $100 \%$ & $87.7-100$ & $86 \%$ & $67.3-96.0$ \\
\hline & 3-6 months & 30 & 22 & 32 & $94 \%$ & $79.2-99.2$ & $69 \%$ & $50.0-83.9$ \\
\hline & 6-12 months & 7 & 4 & 7 & $100 \%$ & $59.0-100$ & $57 \%$ & $18.4-90.1$ \\
\hline \multirow[t]{2}{*}{ Gender } & Boy & 38 & 32 & 40 & $95 \%$ & $83.1-99.4$ & $80 \%$ & $64.4-90.0$ \\
\hline & Girl & 27 & 18 & 27 & $100 \%$ & $82.1-100$ & $67 \%$ & $46.0-83.5$ \\
\hline \multirow[t]{3}{*}{ Symptom score } & 0 to 4 & 46 & 36 & 48 & $96 \%$ & $85.7-99.5$ & $75 \%$ & $60.4-86.4$ \\
\hline & 5 to 10 & 15 & 11 & 15 & $100 \%$ & $78.2-100$ & $73 \%$ & $44.9-92.2$ \\
\hline & over 11 & 4 & 3 & 4 & $100 \%$ & $39.8-100$ & $75 \%$ & $19.4-99.4$ \\
\hline \multirow[t]{2}{*}{ Multiple pathogen } & No & 29 & 25 & 29 & $100 \%$ & $88.1-100$ & $86 \%$ & $68.3-96.1$ \\
\hline & Yes & 36 & 25 & 38 & $95 \%$ & $82.3-99.4$ & $66 \%$ & $48.7-80.4$ \\
\hline \multirow[t]{6}{*}{ CT NPA ${ }^{b}$} & $0-20$ & 3 & 3 & 3 & $100 \%$ & $29.2-100$ & $100 \%$ & $29.2-100$ \\
\hline & $20-25$ & 22 & 22 & 22 & $100 \%$ & $84.6-100$ & $100 \%$ & $84.6-100$ \\
\hline & $25-30$ & 17 & 15 & 17 & $100 \%$ & $80.4-100$ & $88 \%$ & $63.6-98.5$ \\
\hline & $30-35$ & 10 & 6 & 10 & $100 \%$ & $69.2-100$ & $60 \%$ & $26.2-87.8$ \\
\hline & $35-40$ & 10 & 2 & 10 & $100 \%$ & $69.2-100$ & $20 \%$ & $2.5-55.6$ \\
\hline & $40-45$ & 3 & 0 & 3 & $100 \%$ & $2.9-100$ & $0 \%$ & $0-70.8$ \\
\hline \multicolumn{9}{|l|}{ RSV } \\
\hline \multirow[t]{3}{*}{ Age } & $1-3$ months & 12 & 7 & 12 & $100 \%$ & $73.5-100$ & $58 \%$ & $27.7-84.8$ \\
\hline & 3-6 months & 20 & 11 & 20 & $100 \%$ & $82.3-100$ & $55 \%$ & $31.5-77.0$ \\
\hline & 6-12 months & 7 & 2 & 7 & $100 \%$ & $59.0-100$ & $29 \%$ & $7.6-64.8$ \\
\hline \multirow[t]{2}{*}{ Gender } & Boy & 24 & 11 & 24 & $100 \%$ & $85.8-100$ & $46 \%$ & $25.6-67.2$ \\
\hline & Girl & 15 & 9 & 15 & $100 \%$ & $78.2-100$ & $60 \%$ & $32.3-83.4$ \\
\hline \multirow[t]{3}{*}{ Symptom score } & 0 to 4 & 22 & 8 & 22 & $100 \%$ & $84.6-100$ & $36 \%$ & $17.2-59.3$ \\
\hline & 5 to 10 & 10 & 5 & 10 & $100 \%$ & $69.2-100$ & $50 \%$ & $18.7-81.3$ \\
\hline & over 11 & 7 & 7 & 7 & $100 \%$ & $59.0-100$ & $100 \%$ & $59.0-100$ \\
\hline \multirow[t]{2}{*}{ Multiple pathogen } & No & 11 & 10 & 11 & $100 \%$ & $71.5-100$ & $91 \%$ & $58.7-99.8$ \\
\hline & Yes & 28 & 10 & 28 & $100 \%$ & $87.7-100$ & $36 \%$ & $18.6-56.0$ \\
\hline \multirow[t]{6}{*}{ CT NPA ${ }^{b}$} & $0-20$ & 4 & 4 & 4 & $100 \%$ & $39.8-100$ & $100 \%$ & $39.8-100$ \\
\hline & $20-25$ & 11 & 10 & 11 & $100 \%$ & $71.5-100$ & $91 \%$ & $58.7-99.8$ \\
\hline & $25-30$ & 4 & 4 & 4 & $100 \%$ & $39.8-100$ & $100 \%$ & $39.8-100$ \\
\hline & $30-35$ & 7 & 1 & 7 & $100 \%$ & $59.0-100$ & $14 \%$ & $0.4-57.9$ \\
\hline & $35-40$ & 10 & 0 & 10 & $100 \%$ & $69.2-100$ & $0 \%$ & $0-30.8$ \\
\hline & $40-45$ & 3 & 1 & 3 & $100 \%$ & $29.2-100$ & $33 \%$ & $0.8-90.6$ \\
\hline
\end{tabular}

$N P A$ nasopharyngeal aspirate; NS nasal swab; $R S V$ respiratory syncytial virus; $C T$ Cycle threshold value

${ }^{\text {a }}$ One-sided $97.5 \%$ confidence interval was used in case sensitivity was $100 \%$

${ }^{\mathrm{b}}$ The CT-value of the NPA was used as a reference to compare with NS, therefore the sensitivity of the NPA is $100 \%$ for all categories

developed flocked swabs, the sensitivity is even further improved and the flocked swabs have the advantage of being rapid and less traumatic for paediatric patients [28]. However, the sensitivity of the flocked swab in outpatient respiratory tract infections may be lower than in hospitalised patients. Further studies are required considering different types of swabs and patient populations, and should test for a broad spectrum of respiratory pathogens.
Our findings demonstrated a lower sensitivity of the NS, in particular for RSV. Similar results were reported in other studies where conventional, non-amplification-based methods were used [8,9]. Lambert et al. did not test for rhinovirus and this was the most frequently detected virus in our study and elsewhere [11, 29]. No influenza detections were found in our study. This is not explained by sampling bias, because most swabs were taken during 
the winter season, during which both RSV and influenza had their peak incidence. A possible reason may be related to the patient population and the small population size. Another study showed similar results, with rhinovirus and RSV being the most frequently detected [29].

There were a number of limitations of this study. Firstly, one limitation was the timing of sampling. For five cases, sampling occurred 10 days after the onset of illness. Since the viral shedding of RSV is highest between days 0 and 6 , sampling should preferably occur in this period [30]. The high proportion of positive samples, however, indicates that this effect was not a major drawback of this study. Secondly, in this study, pain and discomfort of the collection of the samples was not assessed, but other studies provided reference to this [5]. Finally, it is unknown whether the order of obtaining the specimens may have resulted in a lower detection rate in the NS. It is possible that, by suctioning both nostrils for the NPA, the secretions with virus or viral nucleic acids were reduced. This corresponds with the finding that few mild cases were detected with the NS, as the sensitivity of the NS dropped with lower symptoms score and higher $\mathrm{CT}$ values. Because the order and nature of the sample collection was slightly different from the study performed by Lambert et al., the sensitivity of the NS may be an underestimate, and caution needs to be taken when interpreting the NS sensitivity.

RSV and rhinovirus were commonly detected in infants during primary respiratory infection, and co-infections occurred in about half of the children. The sensitivity of the NPA was higher than the NS, in particular for the detection of RSV and rhinovirus. Although the sensitivity of a method is important, one must also take into account the advantages that different sampling methods offer. The great advantage of the NS is that this method can be performed in outpatient settings without needing special devices, is less costly and causes less distress for the patient than the NPA. Although there is a reduction in sensitivity for RSV, particularly in infants with mild symptoms, the NS is convenient for sampling patients in community studies and can be used for surveillance purposes.

Acknowledgement This work was supported by grants from the Netherlands Asthma Foundation (grant no. 3.2.07.001), WKZ Research Fund (grant no. 2004.02) and a fellowship award of the European Society for Paediatric Infectious Diseases (ESPID).

The medical ethical committee of the Utrecht University Medical Centre (UUMC) approved the study protocol and written informed consent was obtained from the parents of the participating children.

Conflicts of interest The authors declare that they have no conflicting interests in publishing this paper.

Open Access This article is distributed under the terms of the Creative Commons Attribution Noncommercial License which per- mits any noncommercial use, distribution, and reproduction in any medium, provided the original author(s) and source are credited.

\section{References}

1. Bosis S, Esposito S, Niesters HG et al (2008) Role of respiratory pathogens in infants hospitalized for a first episode of wheezing and their impact on recurrences. Clin Microbiol Infect 14(7):677-684

2. Hall CB, Weinberg GA, Iwane MK et al (2009) The burden of respiratory syncytial virus infection in young children. N Engl J Med 360(6):588-598

3. Izurieta HS, Thompson WW, Kramarz P et al (2000) Influenza and the rates of hospitalization for respiratory disease among infants and young children. N Engl J Med 342(4):232-239

4. Miller EK, Lu X, Erdman DD et al (2007) Rhinovirus-associated hospitalizations in young children. J Infect Dis 195(6):773-781

5. Macfarlane P, Denham J, Assous J et al (2005) RSV testing in bronchiolitis: which nasal sampling method is best? Arch Dis Child 90(6):634-635

6. Ahluwalia G, Embree J, McNicol P et al (1987) Comparison of nasopharyngeal aspirate and nasopharyngeal swab specimens for respiratory syncytial virus diagnosis by cell culture, indirect immunofluorescence assay, and enzyme-linked immunosorbent assay. J Clin Microbiol 25(5):763-767

7. Lambert SB, Whiley DM, O'Neill NT et al (2008) Comparing nose-throat swabs and nasopharyngeal aspirates collected from children with symptoms for respiratory virus identification using real-time polymerase chain reaction. Pediatrics 122(3):e615-e620

8. Heikkinen T, Marttila J, Salmi AA et al (2002) Nasal swab versus nasopharyngeal aspirate for isolation of respiratory viruses. J Clin Microbiol 40(11):4337-4339

9. Stensballe LG, Trautner S, Kofoed PE et al (2002) Comparison of nasopharyngeal aspirate and nasal swab specimens for detection of respiratory syncytial virus in different settings in a developing country. Trop Med Int Health 7(4):317-321

10. Waris ME, Heikkinen T, Osterback R et al (2007) Nasal swabs for detection of respiratory syncytial virus RNA. Arch Dis Child 92 (11):1046-1047

11. Lambert SB, Allen KM, Druce JD et al (2007) Community epidemiology of human metapneumovirus, human coronavirus NL63, and other respiratory viruses in healthy preschool-aged children using parent-collected specimens. Pediatrics 120(4): e929-e937

12. Houben ML, Nikkels PG, van Bleek GM et al (2009) The association between intrauterine inflammation and spontaneous vaginal delivery at term: a cross-sectional study. PLoS One 4(8):e6572

13. Gern JE, Martin MS, Anklam KA et al (2002) Relationships among specific viral pathogens, virus-induced interleukin-8, and respiratory symptoms in infancy. Pediatr Allergy Immunol 13 (6):386-393

14. van de Pol AC, Wolfs TF, Jansen NJ et al (2006) Diagnostic value of real-time polymerase chain reaction to detect viruses in young children admitted to the paediatric intensive care unit with lower respiratory tract infection. Crit Care 10(2):R61

15. van Elden LJ, van Loon AM, van Alphen F et al (2004) Frequent detection of human coronaviruses in clinical specimens from patients with respiratory tract infection by use of a novel real-time reverse-transcriptase polymerase chain reaction. J Infect Dis 189 (4):652-657

16. van de Pol AC, van Loon AM, Wolfs TF et al (2007) Increased detection of respiratory syncytial virus, influenza viruses, parainfluenza viruses, and adenoviruses with real-time PCR in samples from patients with respiratory symptoms. J Clin Microbiol 45(7):2260-2262 
17. van Elden LJ, Nijhuis M, Schipper P et al (2001) Simultaneous detection of influenza viruses $\mathrm{A}$ and $\mathrm{B}$ using real-time quantitative PCR. J Clin Microbiol 39(1):196-200

18. van Elden LJ, van Loon AM, van der Beek A et al (2003) Applicability of a real-time quantitative PCR assay for diagnosis of respiratory syncytial virus infection in immunocompromised adults. J Clin Microbiol 41(9):4378-4381

19. van Elden LJ, van Loon AM, van Alphen F et al (2004) Frequent detection of human coronaviruses in clinical specimens from patients with respiratory tract infection by use of a novel real-time reverse-transcriptase polymerase chain reaction. J Infect Dis 189 (4):652-657

20. Cilla G, Oñate E, Perez-Yarza EG et al (2008) Viruses in community-acquired pneumonia in children aged less than 3 years old: High rate of viral coinfection. J Med Virol 80(10): 1843-1849

21. Bonzel L, Tenenbaum T, Schroten H et al (2008) Frequent detection of viral coinfection in children hospitalized with acute respiratory tract infection using a real-time polymerase chain reaction. Pediatr Infect Dis J 27(7):589-594

22. Canducci F, Debiaggi M, Sampaolo M et al (2008) Two-year prospective study of single infections and co-infections by respiratory syncytial virus and viruses identified recently in infants with acute respiratory disease. J Med Virol 80(4):716-723

23. Cilla G, Sarasua A, Montes M et al (2006) Risk factors for hospitalization due to respiratory syncytial virus infection among infants in the Basque Country, Spain. Epidemiol Infect 134 (3):506-513

24. Schildgen O, Müller A, Allander T et al (2008) Human bocavirus: passenger or pathogen in acute respiratory tract infections? Clin Microbiol Rev 21(2):291-304; table of contents

25. Brieu N, Guyon G, Rodière M et al (2008) Human bocavirus infection in children with respiratory tract disease. Pediatr Infect Dis J 27(11):969-973

26. Boivin G, Côté S, Déry P et al (2004) Multiplex real-time PCR assay for detection of influenza and human respiratory syncytial viruses. J Clin Microbiol 42(1):45-51

27. Freymuth F, Vabret A, Cuvillon-Nimal D et al (2006) Comparison of multiplex PCR assays and conventional techniques for the diagnostic of respiratory virus infections in children admitted to hospital with an acute respiratory illness. J Med Virol 78(11):1498-1504

28. Abu-Diab A, Azzeh M, Ghneim R et al (2008) Comparison between pernasal flocked swabs and nasopharyngeal aspirates for detection of common respiratory viruses in samples from children. J Clin Microbiol 46(7):2414-2417

29. Bueno Campaña M, Calvo Rey C, Vázquez Alvarez MC et al (2008) Viral respiratory tract infections in the first six months of life. An Pediatr (Barc) 69(5):400-405

30. Falsey AR, Formica MA, Treanor JJ et al (2003) Comparison of quantitative reverse transcription-PCR to viral culture for assessment of respiratory syncytial virus shedding. J Clin Microbiol 41 (9):4160-4165 